\title{
Pengembangan Pembelajaran Kearsipan Melalui Pelatihan Electronic Filing System (EFS) dengan Program IWSM di Sekolah Menengah Kejuruan (SMK)
}

\author{
Ma'mun Sutisna*1, Tintin Suhaeni', Maya Setiawardani', Mukaram1, Sri Raharso', \\ Ermina Tiorida ${ }^{1}$, Harmon ${ }^{1}$ \\ *1Politeknik Negeri Bandung, Jalan Gegerkalong Hilir Desa Ciwaruga , Bandung, \\ Indonesia
}

\begin{abstract}
In 2017 the 2013 Vocational High School curriculum was revised both in terms of subject content and the name of the expertise competency which was originally the Office Administration into Automation and Office Governance (AOG). One of the changes in the AOG subject is the Archiving subject in the Basic Subject Group of Skills Program. In the syllabus of the original Filing subjects, only manual filing, changed in addition to containing manual file management but also the application of electronic file management. According to the new topic, teachers do not have competence in the field yet, therefore the training is needed. The purpose of this training is to improve teacher's competence in the field of Electronic Filing System (EFS) by using the Image Ware Scan Manager(IWSM) program. This training lasts for five days on the campus, and one week on the field under the guidance of a lecturer at the Business Administration program, Politeknik Negeri Bandung. The result of the training showed that the attendance of participants in the training was $95 \%$, the mastery of training material before and after was $97.6 \%$, and participants as many as 16 people were declared competent.
\end{abstract}

Abstrak - Tahun 2017 Kurikulum SMK tahun 2013 dilakukan revisi baik pada aspek isi mata pelajaran maupun nama kompetensi keahlian yang semula Administrasi Perkantoran menjadi Otomatisasi dan Tata Kelola Perkantoran (OTKP). Salah satu perubahan dalam mata pelajaran OTKP tersebut aalah mata pelajaran Kearsipan dalam kelompok mata pelajaran Dasar Program Keahlian. Dalam silabus mata pelajaran Kearsipan semula hanya kearsipan manual, berubah selain berisi pengelolaan arsip manual tapi juga penerapan pengelolaan arsip elektronik. Terkait dengan adanya topik baru tersebut, guru belum mempunyai kompetensi di bidang tersebut, untuk itu diperlukan pelatihan. Tujuan dari pelatihan ini adalah untuk meningkatkan kompetensi guru dalam bidang Electronic Filing System (EFS) dengan menggunakan program Image ware Scan Manager (IWSM). Pelatihan ini berlangsung selama 5 hari kerja di kampus, dan satu minggu di lapangan di bawah bimbingan dosen program studi Administrasi Bisnis Politeknik Negeri Bandung. Hasil pelatihan menunjukkan bahwa kehadiran peserta dalam mengikuti pelatihan $95 \%$, peingkatan penguasaan materi pelatihan sebelum dan sesudahnya $97,6 \%$, dan peserta sesjumlah 16 orang dinyatakan kompeten.

Kata kunci : Electronic Filing System, memaksimalkan pengajaran, Peningkatan Kompetensi, Scan Manager 


\section{PENDAHULUAN}

Tahun 2017 Kurikulum SMK tahun 2013 dilakukan revisi baik pada aspek isi mata pelajaran maupun nama kompetensi keahlian yang semula Administrasi Perkantoran menjadi Otomatisasi dan Tata Kelola Perkantoran (OTKP). Salah satu perubahan dalam mata pelajaran OTKP tersebut aalah mata pelajaran Kearsipan dalam kelompok mata pelajaran Dasar Program Keahlian. Dalam silabus mata pelajaran Kearsipan semula hanya kearsipan manual, berubah selain berisi pengelolaan arsip manual tapi juga penerapan pengelolaan arsip elektronik

Selain kurikulum yang harus selalu mengikuti perkembangan ilmu pengetahuan dan teknologi, kemampuan guru pun harus selau ditingkatkan, baik dalam hal substantive keilmuan maupun metodologis mengajarnya. Terkait dengan hal tersebut guru-guru di SMK belum mempunyai pengetahuan dan pengalaman dalam hal mata pelajaran E-Filing. Hal ini disebakan karena E-Filing merupakan mata pelajaran baru.

Kompetensi E-Filing tergolong materi yang relatif masih baru, sehingga masih memerlukan pelatihan khusus bagi guru-guru yang mengampu mata pelajaran tersebut, baik dalam hal kompetensi e- filingnya maupun metode untuk mengajarkan e-filing tersebut agar mahasiswa mencapai kompetensi yang diharapkan. Saat ini hampir dalam disetiap lapisan manajemen telah menjadikan teknologi informasi, sebagai sarana kerja utamanya. Dengan digunakannya komputer sebagai sarana kerja, dokumen kerja perkantoran banyak yang dibuat, didistribusikan, digunakan, disimpan, serta ditemukan kembali hanya dengan menggunakan komputer.

Apabila dokumen-dokumen kerja yang berupa file komputer tersebut kemudian disimpan serta dikelola untuk dijadikan referensi dan bukti bagi pelaksanaan tugas dan fungsi individu atau lembaga, maka terciptalah apa yang disebut sebagai arsip elektronik. Arsip elektronik merupakan informasi yang terkandung dalam file dan media elektronik, yang dibuat, diterima, atau dikelola oleh organisasi maupun perorangan dan menyimpannya sebagai bukti kegiatan. Undang-Undang No. 43 Tahun 2009, Bab III Pengalihan.

Bentuk Dokumen Perusahaan Dan Legalisasi, Pasal 12 Ayat 1: Dokumen perusahaan dapat dialihkan ke dalam mikrofilm atau media lainnya. Setiap tahunnya, guru-guru diwajibkan untuk mempersiapkan siswa- siswanya untuk mengikuti ujian praktik di sekolah atau asesmen internal, dan juga asesmen yang dilakukan oleh pihak eksternal (external assessment). Oleh sebab itu, guru-guru wajib membekali dirinya dengan kompetensi yang meliputi kompetensi bidang keahliannya dan metodologi mengajarnya agar mampu mengantarkan siswa-siswanya mencapai kompetensi yang dituntut oleh 
lapangan pekerjaan. pengabdian pada masyarakat ini akan membantu guru-guru SMK untuk meningkatkan kompetensi pembelajaran e-filing dengan menguasai sistem kerasipan elektronik dengan menggunakan program Image Ware Scan Manager (IWSM) sekaligus mampu mengajarkannya.

\section{TINJAUAN PUSTAKA}

Organisasi yang kompetitif biasanya fokus pasa pencapaian strategi dinamis melalui kapabilitas pengetahuan, bukan sekedar mengelola sumber daya organisasi dan aktivitas bisnis berbasiskan produk (Sawyer \& Gammack, 2008). Pengetahuan merupakan distinctive core competence untuk memperoleh keunggulan kompetitif yang langgeng (Raharso, 2009). Kapabilitas pengetahuan jauh lebih penting daripada tanah, tenaga kerja, dan modal finansial (Sharp, 2003). Salah satu cara mengelola pengetahuan adalah mengumpulkan secara sistematis arsip- arsip yang ada di organisasi. Arsip yang lengkap merupakan bahan mentah yang dapat digunakan karyawan maupun pimpinan dalam mengambil keputusan. Saat ini metode kontemporer dalam mengelola arsip adalah pengelolaan arsip berbasis komputer, atau dikenal dengan Electronic filing System. (EFS) (Lestiani,2008)

Penggunaan teknologi informasi dan komunikasi sebagai sarana bantu pengelolaan arsip, terutama untuk jenis arsip konvensional (non-elektronik), yang untuk seterusnya disebut dengan "otomasi kearsipan". Teknologi informasi dan komunikasi dalam hal ini bisa digunakan untuk keperluan administrasi umum, kontrol fisik atas arsip, pengolahan dan penyajian informasi arsip, penemuan kembali informasi arsip, serta penggunaan lainnya yang berkaitan dengan penciptaan, pemeliharaan dan penggunaan, serta penyusutan arsip. Otomasi kearsipan akan sangat berkaitan dengan sistem informasi lain yang diimplementasikan di suatu organisasi. Suatu sistem informasi pada dasarnya dibangun dan dilaksanakan untuk melaksanakan suatu proses bisnis tertentu yang pastilah akan menghasilkan dokumen yang berpotensi untuk menjadi arsip. Karena sistem informasi tersebut berbasis teknologi informasi dan komunikasi dalam pengoperasiannya, maka arsip yang dihasilkannya juga akan berformat digital atau elektronik dan dengan sendirinya menuntut adanya sistem pengelolaan arsip yang berbasis teknologi dan informasi juga. (Budiman,2009)

Electronic Filing System memberikan solusi layanan "Digital Record Management" menggunakan Customizable aplikasi akses arsip digital berbasis web. Electronic Filing System akan menyajikan informasi terintegrasi dari dokumen/arsip digital yang disimpan. Mulai informasi fisik, lokasi penyimpanan, hingga tampilan isi dokumen 
langsung dimonitor komputer klien. Aplikasi dapat menampilkan jumlah arsip yang telah tersimpan, kapan waktu dan oleh siapa terakhir kali suatu arsip dilihat (history), ingga memonitoring log akses seluruh user. Selain kemudahan dan kenyamanan dalam pengoperasiannya, keamanan data adalah prioitas utama. Maka aplikasi akses arsip digital Electronic Filing System (EFS) juga dirancang dengan fitur keamanan data termutakhir, mulai dari identifikasi dan otorisasi user hingga enkripsi data password. Cara dan hak pengaksesan arsip oleh user juga akan dibedakan menurut jabatan user dalam institusi serta tingkat kerahasiaan arsip (top secret, secret, confidential). Layanan Menajemen Arsip Digital hadir untuk memberikan kemudahan dalam akses arsip digital, seketika, kapan saja dan dari mana saja (real time, anytime, anywhere). (Sutisna,2014)

Electronic Filing System adalah sistem solusi untuk manajemen dokumen elektronik. Semua perangkat dan aplikasi yang dibutuhkan untuk solusi ini akan dijabarkan dalam konsep solusi. Implementasi akan dimulai dari proses konversi dokumen kertas ke dokumen elektronik atau biasa disebut document imaging. Document imaging akan menggunakan tools untuk menyimpan data dalam bentuk structured data (data text) dan unstructured data format (image dan file elektronik lainnya). Sistem integrasi ini akan memungkinkan user mencari dokumen dengan lebih mudah dalam menyimpan dan menukan dokumen dengan 5 sistem kearsipan sekaligus yaitu sistem kronologis, nomor, geografis, alphabetik dan subjek.

Electronic Filing System memiliki kemampuan untuk membuat struktur database beragam dan dapat membatasi hak akses bagi user. Sesuai kebutuhan, EFS yang ditawarkan memiliki fitur-fitur: 1) Fungsi akses dokumen, yaitu dokumen yang disimpan di server sistem pengarsipan user bisa mengakses dokumen tersebut secara elektronik oleh lebih dari satu user dalam waktu bersamaan. 2) Fungsi pencarian dokumen, yaitu tiap-tiap dokumen akan diberikan pengelompokan, misalnya judul file, jenis dokumen, nama dokumen dan sebagainya. User bisa mencari dokumen berdasarkan pengelompokan tersebut. 3) Fungsi Database, yaitu sistem database ini dapat dioptimalkan untuk menyimpan dokumen statis (tidak berubah). Karenanya, pencarian dokumen bisa dilakukan dalam waktu singkat. 4) Fungsi Kontrol Akses, yaitu pengaksesan dokumen dilindungi dengan password agar hanya user yang diberi wewenang yang dapat mengaksesnya.(Sutisna,2014)

Banyak program atau sofware khusus untuk menangani otomasi kearsipan yang telah berkembang antara lain SmartFile, eFileCabinet, Daminion Software, FileHold, K-File, WebMerge, K-File Canofile dan Image Ware Scan Manager. Salah satu program atau sofware sistem pengarsipan elektronik yang cukup simple dan mudah dioperasikan tetapi bisa memecahkan masalah kearsipan organisasi besar atupun kecil yaitu Image Ware Scan Manager (IWSM). (Sutisna,2014) 
IWSM adalah sistem pemasukan dokumen yang secara efisien dapat mengcapture dokumen dalam jumlah yang besar dan mengindeksnya secara otomatis agar tertata. Dengan menggunakan program ini sistem kearsipan bisa memiliki keunggulan: 1) Cepat menyimpan dan menemukan dokumen; 2) Pengindeksan yang fleksibel; 3) Pencarian secara full-text; 4) Kecil kemungkinan file hilang: 5) Menghemat tempat; 6) Mengarsip secara digital; 7) Berbagi arsip secara mudah; 8) Meningkatkan keamanan; 9) Mudah dalam me-recovery data. Kemampuan dari IWMS yang penting adalah: automatic indexing, scan/import, search, dan existing worksheet. (Canon, 2002)

Pengembangan pembelajaran kearsipan melalui pelatihan electronic filing system (EFS) dengan program scan manager. Menurut pasal 1 ayat 9 Undang-undang No 13 Tahun 2003 pelatihan kerja adalah keseluruhan kegiatan untuk memberi, memperoleh, meningkatkan, serta mengembangkan kompotensi kerja, disiplin, sikap dan etos kerja pada tingkatan keterampilan dan keahlian tertentu sesuai dengan jenjang dan kualifikasi jabatan dan pekerjaan. Menurut Handoko (2012) mendefiniskan bahwa "Latihan dimaksudkan untuk memperbaiki penguasaan berbagai keterampilan dan teknik pelaksanaan kerja tertentu, terperinci dan rutin. Kesimpulan dari pendapat para ahli di atas, bahwa pelatihan merupakan suatu bentuk bantuan dalam proses pembelajaran yang terorganisir dan sistematis dengan jangka waktu yang relatif singkat untuk meningkatkan pengetahuan dan keterampilan peserta pelatihan yang sifatnya praktis guna mencapai tujuan tertentu.

Tujuan dilaksanakan pelatihan dalam kaitan dengan pekerjaan, Kamil (2010) mengelompokan tujuan pelatihan menjadi lima bidang, yaitu: 1)Memutakhirkan keahlian para karyawan sejalan dengan perubahan teknologi. Melalui pelatihan, pelatih memastikan bahwa karyawan dapat secara efektif menggunakan teknologi-teknologi baru. 2)Mengurangi waktu belajar bagi karyawan untuk menjadi kompeten dalam pekerjaan. 3) Membantu memecahkan permasalahan operasional. 4) Mempersiapkan karyawan untuk promosi, dan 5) Mengorientasikan karyawan terhadap organisasi. Dalam suatu penyelenggaraan pelatihan terdapat bebrapa komponen yang saling berkaitan satu sama lain. Menurut Kamil (2012) komponen-komponen yang terlibat dalam pelatihan yaitu: 1)Instrument input; yaitu masukan sarana dalam pelatihan ini mencakup kurikulum, tujuan pelatihan, sumber belajar, fasilitas belajar, biaya yang dibutuhkan dan pengelola pelatihan; 2) Raw input; yaitu peserta pelatihan dengan berbagai karakteristiknya, seperti pengetahuan, keterampilan dan keahlian, jenis kelamin, pendidikan, kebutuhan belajar, latar belakang sosial budaya, latar belakang ekonomi dan kebiasaan belajarnya; 3) Environment input, yaitu Lingkungan yang menunjang pelaksanaan kegiatan pelatihan, seperti lokasi pelatihan; 4) Process; yaitu Interaksi edukatif yang terjadi dalam pelaksanaan kegiatan pelatihan antara sumber belajar dengan warga belajar 
peserta pelatihan, dan 5) Output; yaitu lulusan yang telah mengalami proses pembelajaran pelatihan.

Langkah-langkah pengelolaan pelatihan menurut Kamil (2012) dapat ditempuh melalui:

1) Rekrutmen peserta pelatihan 2) Identifikasi kebutuhan belajar, sumber belajar dan kemungkinan hambatan, 3) Menentukan dan merumuskan tujuan pelatihan, 4) Menyusun alat evaluasi awal dan evaluasi akhir, 5) Menyusun urutan kegiatan pelatihan, 6) Pelatihan untuk pelatih, 7) Melaksanakan evaluasi awal bagi peserta, 8) Mengimplementasikan pelatihan, 9) Evaluasi akhir dan 10) Evaluasi program pelatihan.

\section{METODE PELAKSANAAN}

Pelaksanaan kegiatan pengabdian pada masyarakat ini terdiri atas beberapa tahapan yaitu melakukan survei dan wawancara lapangan dengan mitra, sekaligus identifikasi kebutuhan pelatihan, persiapan pelatihan, pelaksanaan pelatihan, penilaian pelatihan, evaluasi program, melakukan monitoring dan pembuatan laporan pelatihan dan penarikan kesimpulan. Kegiatan tersebut diilustrasikan dalam bentuk bagan pada gambar 1.

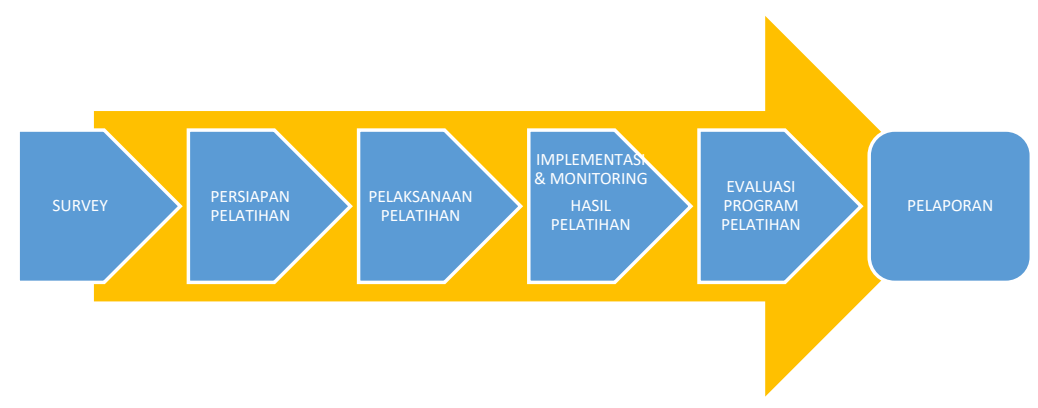

Gambar 1. Tahapan Pelaksanaan Pengabdian pada Masyarakat

\section{Melakukan survey.}

Pada tahap ini dilakukan pengamatan lapangan dilengakapi dengan wawancara terhadap SMK Mitra untuk mengidentifikasi kebutuhan kompetensi dari pembelajaran e-filing dan metodologi mengajarkannya.

2. Persiapan Pelatihan

Pada tahap ini tim melakukan perumusan program, silabus pelatihan, menyiapkan bahan ajar dan jawal pelatihan.

3. Pelaksanaan Pelatihan

Pada tahap ini sebagai inti kegiatan meliputi: 1) Melakukan Tes Awal, 2) Melakukan pelatihan total selama 42 Jam, selama 5 hari. 3) Melakukan tes akhir dengan kriteria keberhasilan pelatihan dilihat dari 3 aspek yaitu: kehadiran rata-rata $80 \%$, peningkatan 
penguasaan materi dari sebelum dan sesudah pelatihan $>75 \%$ dan kurang dari $75 \%$ Tidak Kompeten

4. Implementasi \& monitoring Hasil Pelatihan

Peserta pelatihan mengimplementasikan hasil pelatihan berupa;(1) Penerapan rancangan proyek EFS di satu perusahaan/ instanasi (2) Mengajarkan EFS di SMK nya masing-masing.

5. Evaluasi program

Pada tahap ini dilakukan evaluasi pelaksanaan pengabdian, dengan membagikan kuesioner kepada peserta pelatihan, kemudian menyimpulkan hasil dan evaluasi untuk keberlanjutan pelaksanaan pengabdian pada masyarakat dengan mitra yang sama yaitu dengan masyarakat di SMK yang lainnya.

6. Membuat Laporan

Pada tahap ini dilakukan pembuatan pelaporan pertanggungjawaban pelaksanaan pengabdian pada masyarakat sesuai dengan panduan Unit Penelitian dan pengabdian pada masyarakt(UPPM)

Kurikulum mengharuskan SMK untuk mengembangkan pembelajaran e-filing-EFS. Guru-Guru SMK belum memiliki pengetahuan dan keterampilan untuk melaksanakan hal tersebut. Politeknik Negeri Bandung mempunyai kompetensi IPTEK dalam bidang tersebut, baik SDM, dan Sofware. Transfer Teknologi Pengelolaan Kearsipan secara elektronik atau EFS / efiling dari Politeknik Negeri Bandung kepada Guru-guru SMKN 11 dan SMK Budhi Cendekia dapat terjadi melalui pelatihan EFS/e-filing. Transfer teknologi tersebut Dapat diilustrasikan dalam gambar 2 berikut.

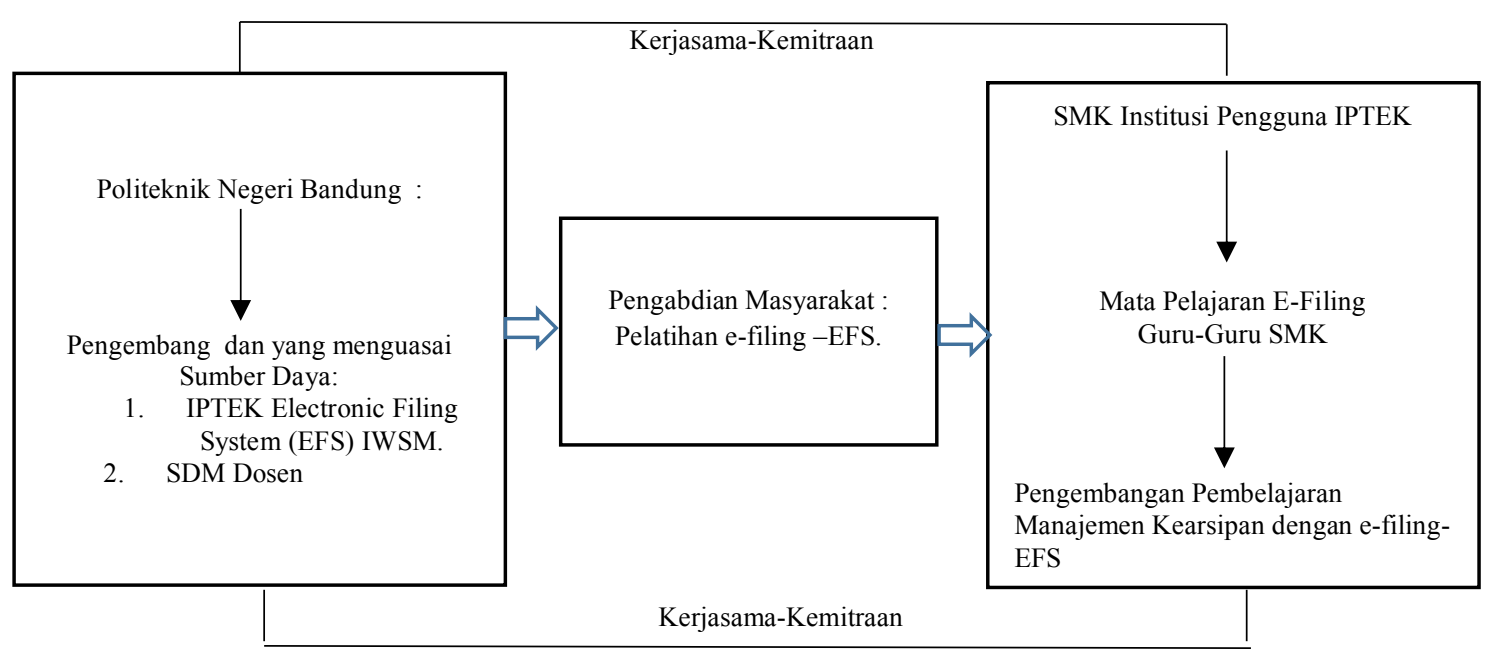

Gambar 2. Ilustrasi Transfer IPTEK Polban - SMK 


\section{HASIL DAN PEMBAHASAN}

\subsection{Melakukan Survey}

Pelaksanaan survei dan wawancara dilakukan untuk ekplorasi beberapa informasi di SMK Mitra sebagai identifikasi awal untuk mengetahui kebutuhan pelatihan dan ketersediaan sumber daya dalam pelaksanaan kegiatan pelatihan. Berdasarkan hasil survei dan wawancara diketahui bahwa dalam kurikulum baru SMK ada mata pelajaran menajemen kearsipan yang didalamnya ada pelajaran e-filing atau sistem Pengarsipan elektronik. Kompetensi tersebut merupakan kompetensi yang dibutuhkan saat ini dan masa datang di instansi pemerintahan maupun swasta. Guru-guru SMK belum mentahui pengarsipan elektronik atau Electrinic Filing System apalagi mengajarkannya kepada siswanya. Guru-guru bidang keahlian OTK berkeinginan untuk mengikuti pelatihan. Kepala sekolah bersedia bekerjasama sebagai mitra dalam pelaksanaan pengabdian pada masyarakat dalam bentuk pelatihan dan monitoring implementasi hasil pelatihan. Berikut adalah peta lokasi SMKN 11 dan SMK Budhi Cendekia Kota Bandung sebagai mitra pengabdian pada masyarakat yang menjadi peserta pelatihan EFS.

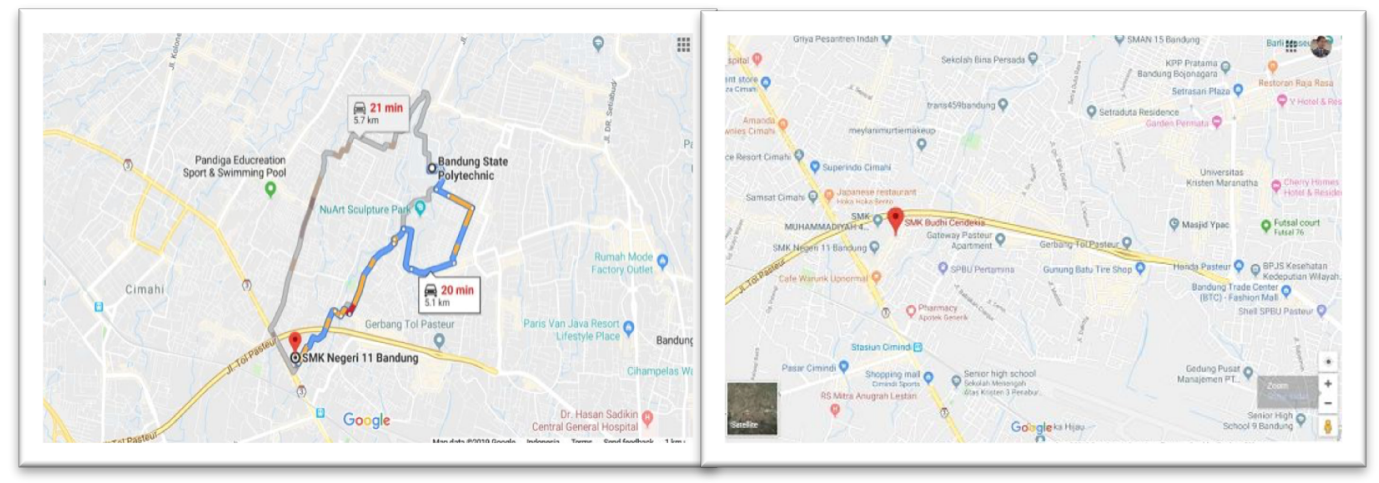

Gambar 3. Peta Lokasi SMK Mitra Pengabdian Pada Masyarfakat

\subsection{Persiapan Pelatihan}

Pada tahap ini tim kordinasi dengan berbagai pihak yang terlibat dalam pelaksanaan pengabdian pada masyarakat. Dilakukan rapat kerja perumusan program pelatihan mengenai waktu, tempat, sarana dan fasilitas yang diperlukan, silabus pelatihan, menyiapkan bahan ajar dan jawal pelatihan. Jadwal pelatihan selama 5 hari rata-rata 9 jam perhari.

\subsection{Pelaksanaan Pelatihan}

Pelaksanaan pelatihan dilakukan dalam beberapa tahap yaitu: 1) Melakukan Tes Awal untuk mengetahui Kemampuan guru SMK tentang pembelajaran e-filing. 2) Melakukan pelatihan total selama 42 Jam, selama 5 hari. Materi pelatihan : (1) merancang sistem kearsipan elektronik, (2 ) pengoperasian program Electronic Filing System (EFS) dan (3) Metode mengajarkan EFS dengan metodologi pembelajaran vokasi, presentasi dari para dosen, diskusi, tutorial, praktik, 
dan diakhiri dengan presentasi proyek dari para peserta berupa rancangan kearsipan elektronik sebuah perusahaan bisnis. Metode-metode pelatihan antara lain Presentasi dari dosen adalah pemaparan materi secara lisan kepada para peserta meliputi pengantar kearsipan elektonik, dan mengoperasikan kearsipan elektronik secara menyeluruh dengan menggunakan program scan manager, dan cara mengajarkan kearsipan elektronik. Diskusi dilakukan untuk mengklarifikasi dan memperoleh feedback dari peserta tentang materi yang disajikan oleh para fasilitator. Kegiatan tutorial dan praktik dilaksanakan ketika para peserta mempraktikkan setiap topik di bawah bimbingan para fasilitator, termasuk dosen dan mahasiswa jurusan Administrasi Niaga, program studi Administrasi Bisnis. Kegiatan pelatihan diakhiri dengan tugas proyek merancang kearsipan elektronik untuk perusahaan selama satu minggu di lapangan, dan dipresentasikan secara berkelompok menurut asal SMK masing-masing.

\subsection{Implementasi \& monitoring Hasil Pelatihan}

Sesuai jadwal pada hari ke 4 dan ke 5 pelatihan, peserta pelatihan melakukan implementasi hasil pelatihan berupa; (1) Penerapan rancangan proyek EFS di satu perusahaan/ instanasi (2) Mengajarkan EFS di SMK nya masing-masing. Peserta menerapkan rancangan EFS dalam bentuk sistem pengarsipan elektronik di SMK, mulai dari membuat media penyimpanan secara elektronik, meinput dokumen, mengindeks, mencari dokumen dan mencetak hasil pencarian dokumen. Para instruktur melakukan monitoring dan penilaian terhadap peserta baik implementasi rancangan EFS maupun praktek mengaajarkan EFS kepada siswanya di SMK masing-masing.

\subsection{Evaluasi program}

Evaluasi program pelatihan EFS bagi guru-guru SMK pada akhir sesi di hari ke 5 . Diadakan tes akhir dengan mengevaluasi terhadap; (1) Penguasaan Pengoperasian Program, (2) Penguasaan Proyek EFS yang telah dibuat oleh peserta pelatihan dan (3) Metode mengajar hasil pelatihan EFS. Setelah melakukan review keseluruhan dari kegiatan teknis evaluasi program dengan membagikan kuesioner kepada peserta pelatihan tentang penyelenggaraan pelatihan EFS.

\subsubsection{Jenis Kelamin Peserta Pelatihan}

Peserta pelatihan yaitu guru-guru SMK Kota Bandung bidang keahlian OTKP, berjumlah 18 orang terdiri atas 12 orang perempuan dan 6 orang laki-laki, seperti tergambar dalam gambar 4. 


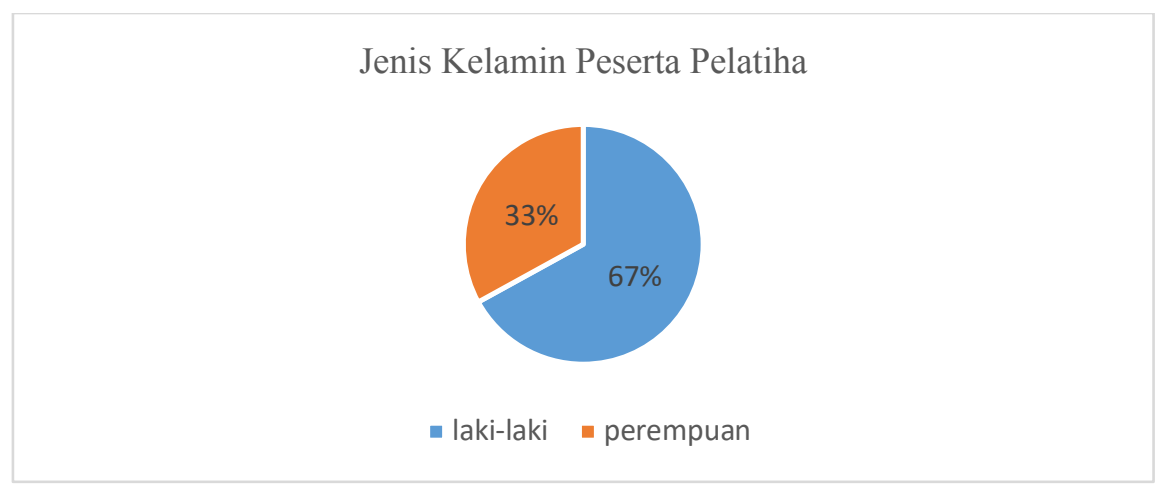

Gambar 4: Jenis Kelamin Peserta Pelatihan

\subsubsection{Kehadiran Peserta Pelatihan}

Kehadiran peserta pelatihan yaitu guru-guru SMK Kota Bandung bidang keahlian OTKP, baik laki-laki maupun perempuan memiliki tingkat kehadiran yang sama yaitu ratarata $95 \%$, seperti dalam bambar 5 .

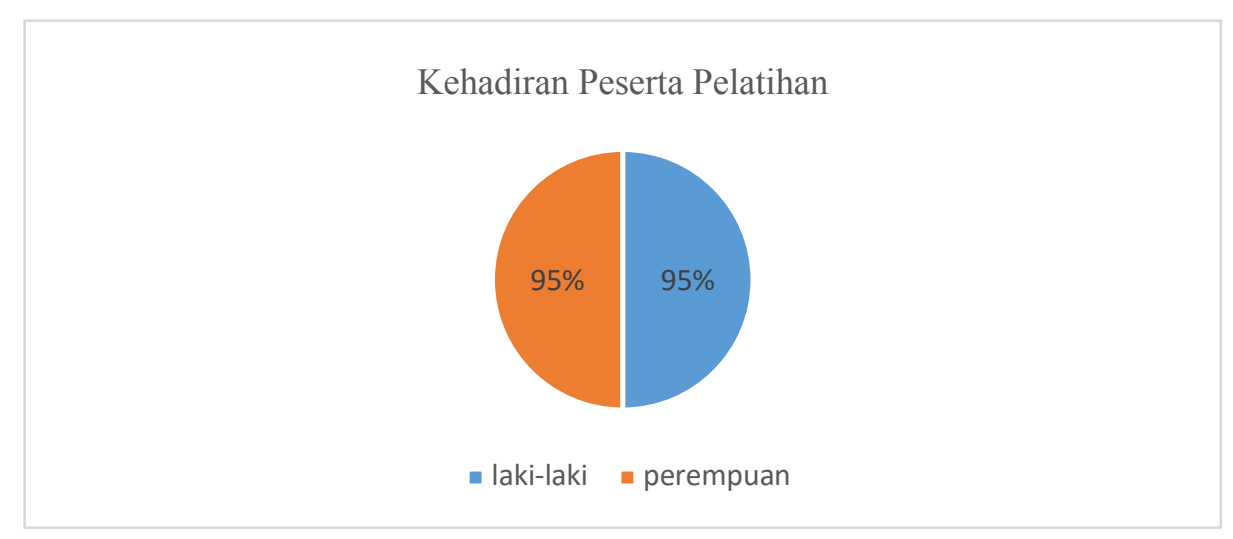

Gambar 5: Kehadiran Peserta Pelatihan

4.5.3 Perbandingan penguasaan materi tes awal dengan tes akhir serta selisihnya

Perbandingan penguasaan materi antara tes awal dengan tes akhir serta selisihnya, menunjukkan rata-rata penguasaan materi pelatihan hasil tes awal 42,6 dan rata- rata tes akhir 84,2, dengan peningkatan sebesar 41,6, atau 97,6\%. Artinya peningkatan penguasaan materi pelatihan dari sebelum mengikuti pelatihan dan sesudah pelatihan naik sebesar 97,6\%. Berdasarkan kriteria peningkatan penguasaan materi pelatihan sangat tinggi, seperti pada gambar 6. 


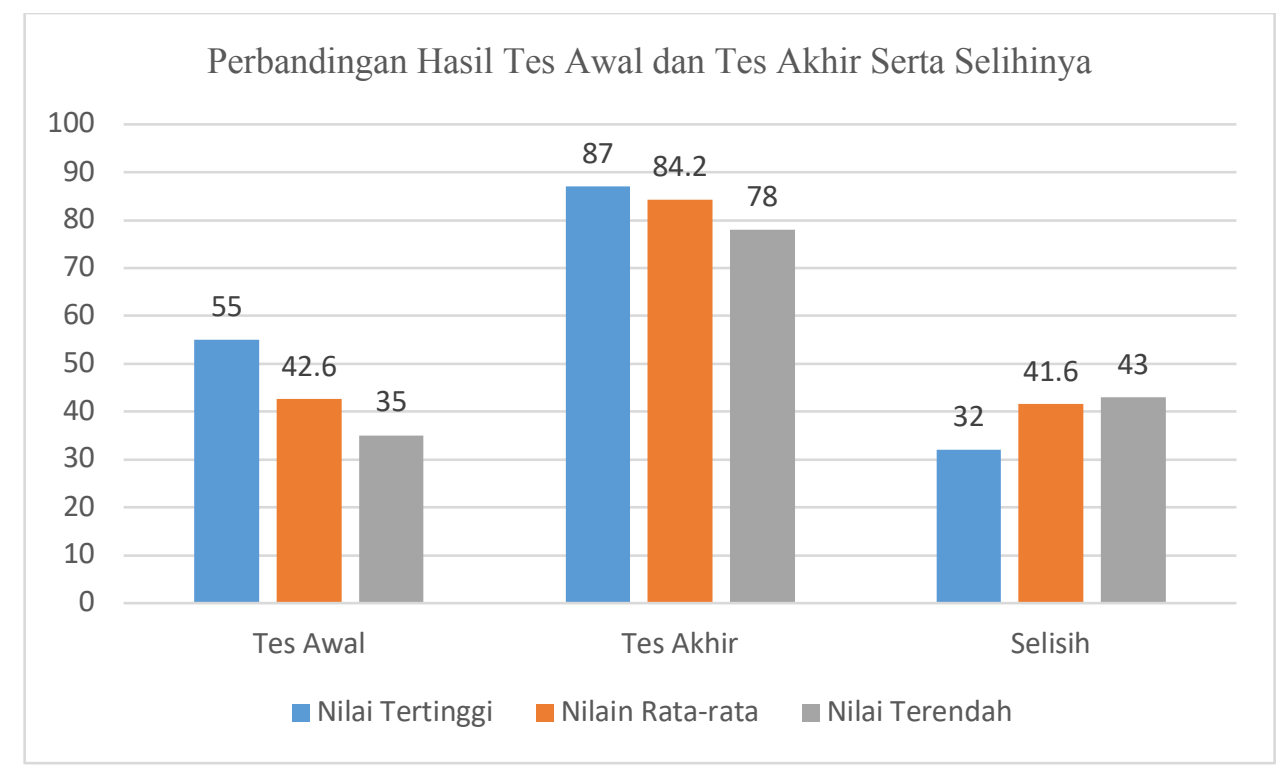

Gambar 6: Perbandingan Hasil Tes Awal dan Tes Akhir Serta Selihinya

\subsubsection{Pencapaian Kompetensi Peseta}

Pencapaian kompetensi peserta pelatihan terhadap keseluruhan materi pelatihan sebanyak 12 orang atau $80 \%$ memiliki nilai rata-rata di atas 80 kompeten dan $11 \%$ cukup kompeten, seperti dalam gammbar 7.

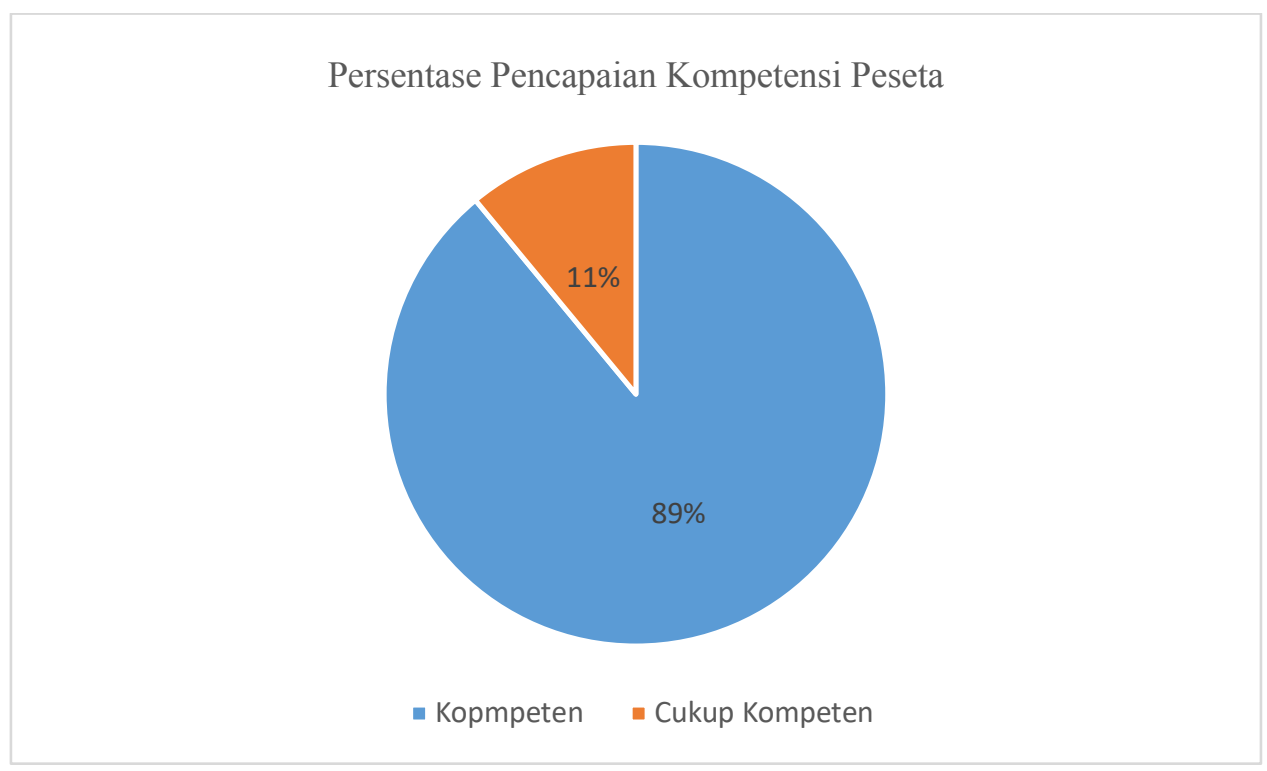

Gambar 7: Pencapaian Kompetensi Peserta Pelatihan 


\subsubsection{Penilaian Peserta Terhadap Penyelenggaraan Program Pelatihan.}

Pencapaian kompetensi peserta pelatihan terhadap keseluruhan materi pelatihan sebanyak 12 orang atau $80 \%$ memiliki nilai rata-rata di atas 80 kompeten dan $11 \%$ cukup kompeten. Hasil kuisioner penilaian yang diperoleh dari responden (peserta pelatihan) terhadap kegiatan pelatihan, berdasarkan pada 5 kelompok pernyataan seperti disajikan pada tabel 1. Kategori penilaian peserta atau responden adalah baik sekali, baik, cukup, kurang dan kurang sekali.

Tabel 1. Rubrik Instrumen Evaluasi Program

\begin{tabular}{|r|l|l|}
\hline \multicolumn{1}{|c|}{ No } & \multicolumn{1}{|c|}{ Uraian } & \multicolumn{1}{|c|}{ Katgori } \\
\hline 1 & Isi materi Pelatihan & 1. Baik Sekali \\
\hline 2 & Metode Penyampaian dalam Pelatihan & 2. Baik \\
\hline 3 & Instruktur Pelatihan dalam penyapaian Materi & 3. Cukup \\
\hline 4 & Sumber Belajar & 5. Kurang \\
\hline 5 & Partisipasi Peserta dalam Pelatihan & \\
\hline
\end{tabular}

Penilaian dari peserta terhadap penyelenggaraan pelatihan yang dilaksanakan sangat baik. Hal ini dapat dilihat dari grafik persentase penilaian peserta dalam grafik yang disajikan pada Gambar 8. Penilian yang paling tinggi skor 94\% terutama pada aspek fasilitator berkenaan dengan penguasaan keilmuan atau substansi pelatihan dan yang paling kecil $82 \%$ penilaiannya terhadap parisipasi peserta dalam pelaaksanaan pelatihan.

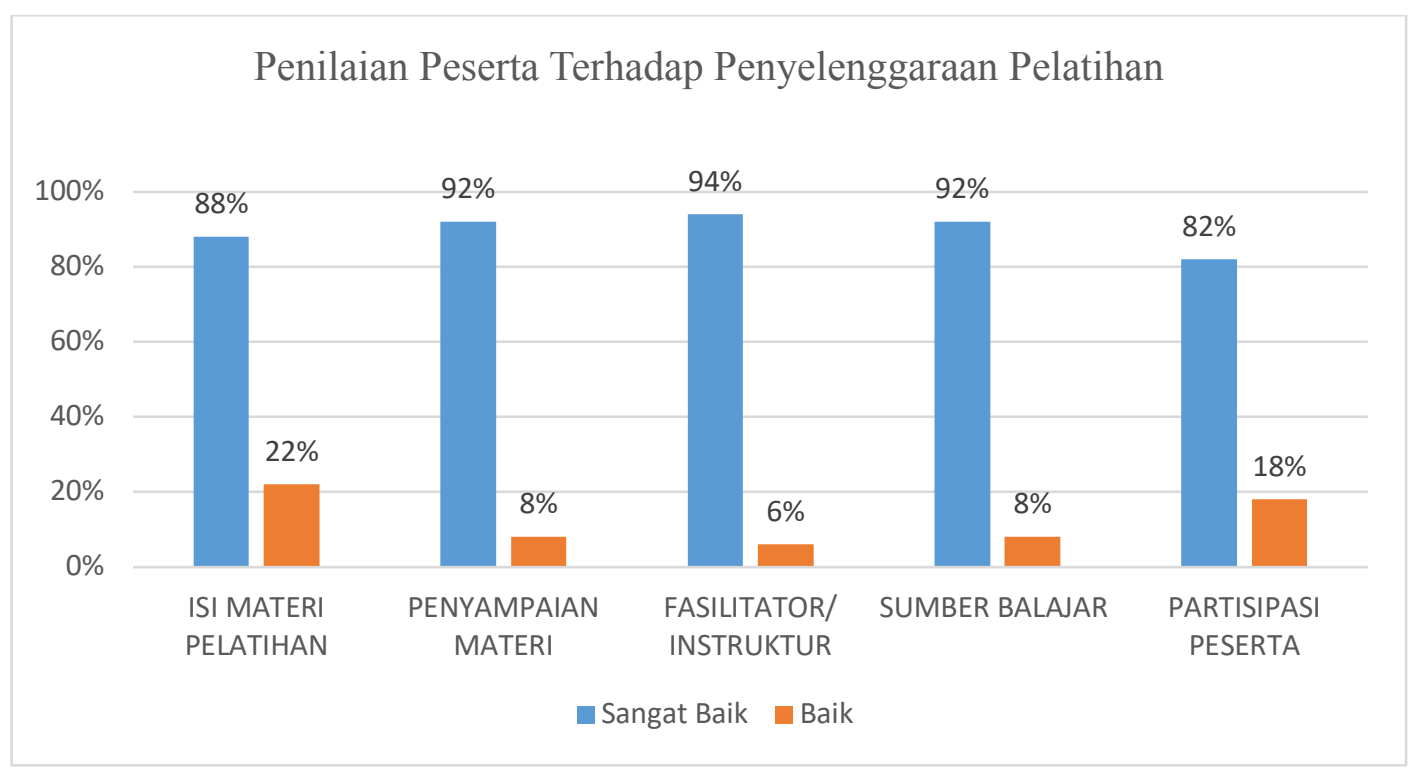

Gambar 8: Penilaian Peserta Terhadap Penyelenggaraan Pelatihan.

\subsection{Pembahasan}

Secara keseluruhan hasil kegiatan pelatihan peningkatan kompetensi Electronic Filing System (EFS) untuk memaksimalkan pembelajaran e-filing dengan program Scan Manager Sekolah Menengah Kejuruan (SMK) di Kota Bandung ini berlangsung dengan baik. Artinya 
pelaksanaan pelatihan telah sesuai dengan rencana dalam proposal yang diajukan. Jumlah SMK yang mengikuti pelatihan ini sebanyak 3 hadir dalam pelatihan. Artinya persentase keikutsertaan insitusi peserta yang diundang sebesar 100\%, sedangkan keikutsertaan peserta yang diundang sebanyak 20 orang yang hadir sebanyak 18 orang atau $90 \%$, dan rata-rata kehadiran mengikuti pelatihan peserta laki-laki dan perempuan sama sebesar 95\%. Artinya tidak ada perbedaan kehadiran antara peserta laki-laki dan peserta perempuan. Dalam proses kegiatan pelatihan, masing-masing peserta menggunakana 1 perangkat komputer yang sudah diinstall Software IWMS. Bahan ajar berupa modul pelatihan, power point materi pelatihan dan video tutorial penggunaan program EFS disiapkan baik dalam CD maupun di komputer masingmasing. Dengan pola 1 orang peserta dan 1 unit komputer dilengkapi modul yang dirancang scara step by step pengoperasioan program dan video turorial, maka peserta dapat belajar sambil melakukan (learning by doing). Penyampaian materi pelatihan dilakukan dengan bantuan LCD Proyektor, dilengkapi White Board, sehingga proses komunikasi dapat berlangsung dengan baik, terutama pada saat penyampaian materi yang berupa tutorial step-bystep.

Pada proses pelaksanaan pelatihan dilakukan dengan prosedur:

1. Setiap tahapan kegiatan (tiap modul) dilakukan penilaian terhadap kemampuan peserta dan hasilnya dikonfirmasikan kepada peserta. Dengan cara seperti itu perkembangan kemampuannya peserta dapat dipantau sekaligus mebantu peserta yang perlu diperbaiki atau dibetulkan.

2. Peserta diminta melaksanakan praktik dan simulasi dari tiap modul melalui kegiatan work shop. Fasilitator yang terdiri dari dosen dan mahasiswa menjadi pendamping peserta dalam pelaksanaan work shop,

3. Peserta diminta melaksanakan praktik merancang kearsipan elektronik di laboratorium dan membuat proyek perancangan kearsipan elektronik secara berkelompok. Hasil dari proyek dipresentasikan dan disimulasikan di tempat fasilitator. Setiap perserta bergiliran menampilkan kemampuannya baik dalam pengopersian IWSM, merancang proyek EFS dan mengimplementasikan di SMK masing-masing.

Penilaian dilakukan dengan tes awal dan tes akhir. Tes awal dilakukan untuk mengetahui kemampuan awal dari peserta terhadap materi pelatihan yang akan dilakukan. Materi tes merupakan garis besar atau mewakili seluruh materi pelatihan baik yang bersifat praktik maupun yang bersifat teori. Dari hasil yang dicapai oleh peserta pelatihan saat tes awal skor rata-rata yaitu 42,6,ini berarti masuk pada ketegori sangat kurang. Tes akhir dilakukan untuk mengetahui pencapaian kompetensi setelah mengikuti pelatihan. Hasil penilaian pelatihan diperoleh nilai rata- rata 84,2, masuk kateori sangat baik. Sehingga delta tes awal dan akhir sebesar 41,6 atau 97,6\%. masuk pada kegori sangat tinggi. Artinya 
pelaksanaan pelatihan dapat dikategorikan berjalan dengan baik dan hasilnya sangat memuaskan. Dilihat dari jumlah peserta yang mencapai kualifikasi kompeten sebanyak 16 orang semuanya kompeten. Artinya pelatihan berhasil mencapai target dari pelatihan yaitu semua peserta pelatihan menguasai materi pelatihan.

Dari aspek penyelenggaraan, komponen-komponen yang dievaluasi adalah materi pelatihan, proses pelatihan, fasilitator, serta kelancaran pelaksanaan pelatihan secara keseluruhan yang dinilai oleh peserta melalui kuisioner Hasil kuisioner evaluasi program kepada peserta, dan respon yang kami peroleh dari segi isi materi pelatihan $88 \%$ menyatakan sangat baik, baik ditinjau dari segi kualitas maupun kuantitasnya. Isi materi cukup aplikatif, rinci, menarik, dan mudah dimengerti. Dilihat dari segi metode penyampaian $92 \%$ dinilai sangat baik. Begitu juga dengan para pengajar/fasilitator dapat melaksanakan fungsinya dengan sangat baik dan selalu berupaya untuk membuat kelas dalam keadaan dinamis. Berdasarkan kompetensi fasilitasor atau instruktur pelatihan $94 \%$ menyatakan para fasilitator memperlihatkan pengetahuan pada areanya sangat baik. Dilihat dari kesempatan partisipasi peserta dalam pelatihan $92 \%$ menyatakan partisipasi peserta dirasakan sangat positif sehingga lebih mendorong terciptanya kondisi yang menyenangkan. Dilihat dari segi sumber belajar atau bahan ajar yang digunakan dalam pelatihan $82 \%$ menyatakan sumber belajar sangat baik dan mudah untuk dibaca dan digunakan.

Komentar umum yang disampaikan oleh para peserta paling banyak adalah menginginkan waktu pelatihan agar diperpanjang, dan komposisi praktik disarankan lebih banyak lagi daripada teori. Secara umum peserta berminat untuk mengikuti kembali pelatihan sejenis dengan pendalaman beberapa topik secara spesifik yang ada dalam pelatihan ini.

\section{KESIMPULAN}

Pengembangan Pembelajaran Kearsipan Melalui Pelatihan Electronic Filing System (EFS) dengan Program Image Ware Scan Manager di Sekolah Menengah Kejuruan (SMK) Kota Bandung, berjalan secara baik.

1. Ada sejumlah faktor yang turut mendukung terlaksananya pelatihan yaitu:

a. Kesiapan Tim penyelenggara pengabdian ada mayarakat untuk melaksanakan pellatihan EFS dalam bentuk rancangan program, silabus pelatihan, materi pelatihan, bahan ajar dan jadwal pelatihan serta kordinasi dengan fihak terkait.

b. Kesiapan Fihak SMK mitra pengabdian ada mayarakat untuk berpartisipasi melaksanakan pellatihan EFS dalam bentuk penugasan peserta, kehadiran dan motivasi dan partisipasi yang selama proses pelatihan.

c. Kesiapan dan semangat para peserta kegiatan ini begitu besar untuk mendapatkan pengetahuan dan keterampilan yang disiapkan oleh tim pengabdian. Terdapat 
peningkatan yang dilihat melalui pelatihan dan pendampingan pada kegiatan berikutnya.

d. Kerjasam dan kordinasi antara penyelenggara dan mitra pengadian pada masyarakat selama survey, persiapan, pelaksanaan pelatihan, implementasi dan monitoring serta evaluasi program yang sangat baik.

2. Kehadiran peserta pelatihan, dan instruktur dalam pelaksanaan pelatihan hampir seratus persen.

3. Penguasaan peserta terhadap materi pelatihan sangat tinggi, dapat dilihat dari perbandingan tes awal dan tes akhir serta selisih nilai tes awal dan tes akhir. Sedangkan dilihat dari pencapaian penguasaan kompetensi secara kelulusan peserta mencapai tingkat kompeten.

4. Respon atau penilaian peserta terhadap penyelenggaraan pelatihan sangat baik terutama pada aspek penguasaan subtansi fasilitataor dalam pelatihan.

5. Para peserta menginginkan waktu pelatihan agar diperpanjang, dan komposisi praktik disarankan lebih banyak lagi daripada teori. Peserta berminat untuk mengikuti kembali pelatihan sejenis dengan pendalaman beberapa topik secara spesifik yang ada dalam pelatihan ini.

\section{UCAPAN TERIMA KASIH}

Pengabdian pada masyarakat Politeknik Negeri Bandung melalui kegiatan Pelatihan Peningkatan Kompetensi Electronic Filing Systm (EFS) untuk memaksimalkan pengajaran E-Filing dengan Program Scan Manager Di Sekolah Menengah Kejuruan (SMK), Kota Bandung dapat terlaksana dengan baik. Tujuan serta target dari pelaksanaan pelatihan dapat tercapai. Syukur Alhamdulilah dipanjatkan pada Tuhan Yang Maha Esa atas rahmat dan karuniaNya pelatihan ini berjalan lancar. Dalam kesempatan ini tim menyampaikan terima kasih dan penghargaan kepada:

1. Kepala UPPM Politeknik Negeri Bandung dan jajarannya yang telah memfasilitasi kegiatan pengabdian kepada masyarakat berupa pelatihan Peningkatan Kompetensi Electronic Filing System (EFS) Untuk Memaksimalkan Pengajaran E-Filing dengan Program Scan Manager Di Sekolah Menengah Kejuruan (SMK).

2. Manajemen Jurusan Administrasi Niaga dan Jajarannya, rekan-rekan dosen sebagai tim Pengabdian, laboran dan mahasiswa sebagai tutor pelatihan yang telah bekerja sama untuk mewujudkan kegiatan ini.

3. Pihak Sekolah Menengah Kejuruan Negeri (SMKN 11) dan Sekolah Menengah Kejuruan Budhi Cendekia Kota Bandung, guru-guru khususnya peserta pelatihan EFS yang begitu gigih serius dalam mengikuti pelatihan sampai tuntas.

Akhirnya Tim Pengabdian pada Masyarakat Politeknik Negeri Bandung berharap kegiatan 
seperti ini terus berlanjut dan bermanfaat bagi Polban dan guru-guru SMK untuk meningkatkan kompetensi pembelajaran e-filing dalam Manajemen Kearsipan. Tim Pengabdian pada masyarakat polban masih terus melakukan pemantauan dan pendampingan, agar implementasi hasil pelatihan ini betul-betul terlaksana dan memperbaiki kualitas kompetensi lulusan SMK. 


\section{DAFTAR PUSTAKA}

Budiman, MR(2009). Dasar Pengelolaan Arsip Elektronik. Yogyakarta : Badan Perpustakaan dan Arsip Daerah.

Handoko, T. Hani. 2012. Manajemen Personalia dan Sumber Daya Manusia. Yogyakarta : BPFE.

Kamil, Mustofa. 2012. Model Pendidikan dan Pelatihan (Konsep dan Aplikasi). Bandung: Alfabeta

Lastiyani, MN (2008) Manajemen Arsip Elektronik. www.bacaanonline.com/manajemen-arsip -elektronik-monika-nur-lastiyani, diunduh pada tanggal 7 Agustus 2019.

Polban, (2019). Profil Polban Politeknik Negeri Bandung, https://www.polban.ac.id/ tentang-polban/profil-polban/ diunduh pada, 22 Agustus 2019.

Polban, (2019). Visi Misi DIV Administrasi Bisnis, https://www.polban.ac.id/akuntansiniaga/div-adminitrasi-bisnis/ diunduh pada, 22 Agustus 2019.

Raharso, S. (2009), Orientasi Pasar, Inovasi, dan Kinerja Organisasi Ritel, Manajemen Usahawan, No.3, tahun ke. 38, Hal. 26-29.

Raharso, S. (2010). Kepemimpinan Pengetahuan (Knowledge leadership dalam manajemen pengetahuan), Manajemen Usahawan, No. 1 Tahun ke 39 , Hal 15-26.

Refina, L. (2002). Analisis Behavioral intention:Kasus Pelaksanaan Hak Cipta Software Komputer, Jurnal Manajemen Indonesia, Vol. 1, Hal 19-29.

Saenz, Josune, Aramburu, Nekane, Blance, Carlos,E. (2012). Knowlwdge Sharing and innovatin in Spanish and Colombian high-tech firms, Jurnal of Knowledge Management, Vo. 16, ISS6, pp. 919-933

Sarosa, S. (2012). Penelitian Kuantitatif, Dasar-dasar, Jakarta: Indeks

Sharp, D. (2003). Knowlegde Management today: Chalenges and opportunities Information System Management, Spring, pp.32-37.

Sutisna, M. (2014). Sistem Pengarsipan Elektronik, Lab EFS Jurusan Administrasi Niaga Polban.

Undang-Undang Republik Indonesia Nomor 43 Tahun 2009, Tentang Kearsipan

Undang-undang No 13 Tahun 2003 tentang Ketenagakerjaan, pasal 9 ayat 1.

User's Guide IW Scan Manager, Canon, 2002 